suggests that a little fibrin was lost by solution; the described procedure was therefore preferred: in this also, the manipulation of fibrin was found to be easier in the smaller volume.

\section{Table 4. Effect of dilution on clot weight}

(Weights of clots from twelve $5.0 \mathrm{ml}$. portions of one sample of plasma: in six instances the recalcified mixture was diluted five times.)

\begin{tabular}{ccc} 
& \multicolumn{2}{c}{ Clot weight (mg.) } \\
\cline { 2 - 3 } Replicates & Diluted & Undiluted \\
1 & $14 \cdot 1$ & $14 \cdot 1$ \\
2 & $13 \cdot 9$ & $14 \cdot 0$ \\
3 & $13 \cdot 6$ & $13 \cdot 8$ \\
4 & $13 \cdot 6$ & $14 \cdot 1$ \\
5 & $13 \cdot 8$ & $14 \cdot 1$ \\
6 & $13 \cdot 4$ & $14 \cdot 1$ \\
Mean & $13 \cdot 73$ & $14 \cdot 03$
\end{tabular}

Ash weight of clot. To exclude systematic error from mineral content (Foster \& Whipple, 1922), two groups of three clots from $5.0 \mathrm{ml}$. normal plasma samples were pooled and weighed. Thereafter they were ashed and re-weighed. In neither instance did the combined weight of ash from the pooled clots exceed the limit of balance error ( $\pm 0 \cdot 1 \mathrm{mg}$.).

\section{DISCUSSION}

Effect of sample volume. The inverse relation of fibrinogen concentration to the plasma sample volume is curious. It is interesting that a similar inverse relation is apparent in the fibrin dry-weight data of Foster \& Whipple (1922) and of Howe (1923), though in neither report does it receive comment; in Howe's data the magnitude of the effect is very small. The error, about $5 \%$ or less per ml. below $5 \mathrm{ml}$., is obviously small compared with differences expected between persons, if approximately the same volume of plasma, 3-4 ml., is always used.

Effect of sample dilution. The findings suggest that plasma samples should not be much diluted at recalcification, although again the error, a loss of $2 \%$ on clot weight with fivefold dilution of the reaction mixture, is small compared with differences to be expected between persons.

\section{SUMMARY}

1. Daily determinations on a stored plasma sample showed a significant increase of clot weight from the fourth day after withdrawal.

2. There is an inverse relation between sample size and determined fibrinogen concentration.

3. Clot weights obtained by recalcification agreed well with those obtained by adding thrombin.

4. Dilution of the sample at recalcification reduced the weight of clot obtained.

5. The ash weight of the clot was negligible.

The author is indebted to the Medical Research Council for a grant. It is a pleasure to acknowledge the assistance of Dr P. Armitage of the Medical Research Council Statistical Research Unit, London School of Hygiene and Tropical Medicine, in the analyses of the numerical data.

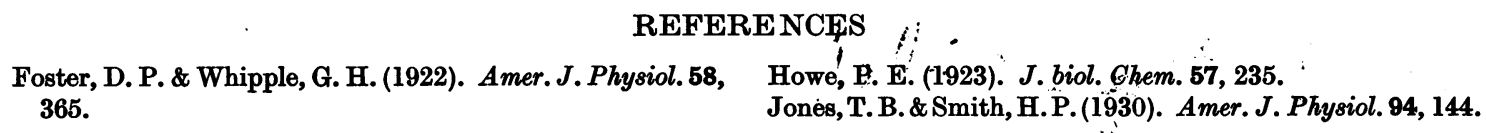

\title{
Bacterial Arylsulphatase
}

\author{
By J. E. M. WHITEHEAD \\ Department of Bacteriology, St Thomas's Hospital Medical School, London, S.E. 1 \\ AND A. R. MORRISON AND L. YOUNG \\ Department of Biochemistry, St Thomas's Hospital Medical School, London, S.E. 1
}

(Received 31 December 1951)

It is known that in plants and animals there occur enzymes which catalyse the hydrolysis of sulphuric acid esters. These enzymes, the sulphatases, have recently been reviewed by Fromageot (1950). The sulphatases differ with respect to the type of sulphuric acid ester upon which they act, and they include arylsulphatase (phenolsulphatase), which hydrolyses arylsulphuric acids. The existence of arylsulphatase was first demonstrated by Derrien (1911) who observed that extracts of the shell fish, Murex trunculus, hydrolyse potassium indoxyl sulphate. An enzyme with similar activity was later found to be present in Aspergillus oryzae by Neuberg \& Kurono (1923), and when evidence became available concerning its specificity it was named 'phenolsulphatase' (Neuberg \& Simon, 1932). 
Recently, the more satisfactory name 'arylsulphatase' has been applied to this enzyme (Robinson, Spencer \& Williams, 1951). Arylsulphatase has been shown to be present in the tissues of higher animals (Neuberg \& Simon, 1925; Rosenfeld, 1925; Hommerberg, 1931; Huggins \& Smith, 1947) and also in neoplasms of the rat (Huggins \& Smith, 1947).

Hitherto, no extensive study of the distribution of arylsulphatase among bacteria appears to have been made. An indication that this enzyme is present in some species of bacteria was obtained, however, by Barber, Brooksbank \& Kuper (1951). These workers, while using sodium phenolphthalein monoglucuronidate and sodium phenolphthalein diphosphate as substrates for the study of glucuronidase and phosphatase in staphylococci, kindly undertook to test the same organisms for arylsulphatase using, as substrate, potassium phenolphthalein disulphate synthesized by two of us (A.R.M. and L.Y.). Of the 160 strains of Micrococcus pyogenes and the seventy-five strains of coagulase-negative staphylococci tested by Barber et al. (1951), two showed faint phenolsulphatase activity. More marked arylsulphatase activity was shown, however, by an aerobic sporing bacillus encountered as a contaminant, and by a strain of Salmonella schottmuelleri.

In the present investigation, a wide range of bacterial species has been examined for the presence of arylsulphatase and some species have been found to contain the enzyme. The substrate used for testing for the presence of the enzyme was potassium phenolphthalein disulphate. With some bacterial species tests were also carried out using potassium 1-naphthylsulphate as substrate. The synthesis of potassium phenolphthalein disulphate does not appear to have been reported previously and an account of the method used to prepare the compound is given in the present paper, together with a description of some of its properties. A preliminary study of the separation of bacterial arylsulphatase has been made and an account is given of the preparation, from a strain of Mycobacterium piscium, of cell-free aqueous extracts with arylsulphatase activity.

A preliminary account of the work described in this paper has been published (Young, Morrison \& Whitehead, 1952).

\section{SUBSTRATES USED FOR THE STUDY OF BACTERIAL ARYLSULPHATASE}

\section{Potassium phenolphthalein disulphate}

Synthesis of potassium phenolphthalein disulphate. Most of the methods used for the synthesis of arylsulphuric acids are based on a procedure developed by Verley (1901) in which chlorosulphonic acid is added slowly to a chilled solution of an organic base in an anhydrous organic solvent. The addition product of the chlorosulphonic acid and the organic base is then allowed to react with the phenol, and the organic base salt of the arylsulphuric acid thus formed is converted to the potassium salt by treatment with aqueous potassium hydroxide. A number of organic bases and solvents have been used in this procedure, e.g. pyridine and carbon disulphide (Verley, 1901), pyridine and chloroform (Czapek, 1914), dimethyl- or diethyl-aniline and carbon disulphide (Burkhardt \& Lapworth, 1926). In the present investigation it was found that potassium phenolphthalein disulphate can be prepared in fair yield by the above procedure using pyridine as the base and chloroform as a solvent.

A mixture of $12.5 \mathrm{ml}$. of dry pyridine and $12.5 \mathrm{ml}$. of redistilled $\mathrm{CHCl}_{8}$ in a $100 \mathrm{ml}$. beaker (tall type) was cooled in an ice bath, and while the mixture was stirred, $5.0 \mathrm{ml}$. of chlorosulphonic acid were run in slowly down the side of the beaker from a tap funnel. To this solution were added quickly, with stirring, $8.0 \mathrm{~g}$. of phenolphthalein in $15 \mathrm{ml}$. of $\mathrm{CHCl}_{3}$. The ice bath was then removed and the contents of the beaker were stirred for $2 \mathrm{hr}$., after which they were allowed to stand at room temperature overnight. The beaker was then placed in an ice bath and while its contents were stirred, $80 \%$ aqueous $\mathrm{KOH}$ solution (w/v) was added until the mixture was just alkaline to litmus $(14 \mathrm{ml}$. of the $\mathrm{KOH}$ solution were required). The mixture was stirred for $10 \mathrm{~min}$. after the addition of the $\mathrm{KOH}$ solution had been completed and it was then poured, with stirring, into $150 \mathrm{ml}$. of absolute ethanol. The precipitate which formed was allowed to settle in the refrigerator and was then separated by centrifuging. The solid material was then extracted on a water bath with three $100 \mathrm{ml}$. portions of a mixture of $80 \%$ ethanol and $20 \%$ water $(v / v)$. During this process the mixture was kept just alkaline to phenolphthalein by the addition of a few drops of $\mathrm{KOH}$ solution. The extracts were cooled separately to room temperature and were then cooled in an ice bath. A heavy precipitate formed in the first extract and was separated by filtration. The filtrate was combined with the second and third extracts, $900 \mathrm{ml}$. of absolute ethanol were added, and the precipitate which formed was filtered off. The combined precipitates were dissolved in a minimum of water and the compound was salted out by the addition, with vigorous stirring, of $80 \%$ aqueous $\mathrm{KOH}$ solution $(\mathrm{w} / \mathrm{v})$. The potassium phenolphthalein disulphate was removed by filtration on a sintered-glass filter, washed with absolute ethanol, and dried. The product weighed $10.5 \mathrm{~g}$. and this corresponded to a yield of $64 \%$ based on the amount of phenolphthalein used. The compound was crystallized twice from water and was then dried over $\mathrm{P}_{2} \mathrm{O}_{5}$ in vacuo at room temperature. The product gave negative tests for phenolphthalein, inorganic sulphate, chloride, carbonate and bicarbonate. It gave strong positive tests for phenolphthalein and inorganic sulphate after it had been boiled in $\mathrm{N}-\mathrm{HCl}$ solution for $1 \mathrm{~min}$. (Found: $\mathrm{C}, 36 \cdot 7 ; \mathrm{H}, 2.9$; $\mathrm{S}, 9 \cdot 8 ; \mathrm{K}, 17 \cdot 0 . \mathrm{C}_{20} \mathrm{H}_{13} \mathrm{O}_{11} \mathrm{~S}_{2} \mathrm{~K}_{3} .2 \mathrm{H}_{2} \mathrm{O}$ requires $\mathrm{C}, 37 \cdot 1 ; \mathrm{H}, 2 \cdot 6$; $\mathrm{S}, \mathbf{9} \cdot 9, \mathrm{~K} ; \mathbf{1 8} \cdot 1 \%$. Micro-analyses by Drs Weiler and Strauss, Oxford.) The compound was very soluble in water and was almost insoluble in ethanol. It was obtained as fine colourless needles when precipitated from aqueous solution by the 
addition of ethanol, and as rectangular plates when crystallized from water.

Gravimetric determination of phenolphthalein and sulphate liberated by acid hydrolysis of the compound. Phenolphthalein is almost insoluble in dilute $\mathrm{HCl}$ solution, and it was thus possible to carry out a gravimetric determination of the amount of phenolphthalein liberated on complete hydrolysis of the potassium phenolphthalein disulphate obtained by the procedure just described. The amount of sulphate liberated on hydrolysis was determined gravimetrically as $\mathrm{BaSO}_{4}$ at the same time. To a solution of $0.06429 \mathrm{~g}$. of the compound dissolved in $1 \mathrm{ml}$. of water in a small Pyrex filter beaker (fitted with a sintered-glass filter plate) was added $1 \mathrm{ml}$. of $2 \mathrm{~N}-\mathrm{HCl}$. The vessel and its contents were heated in a boiling-water bath for $\mathbf{3 0} \mathrm{min}$. and then cooled in an ice bath. The crystalline precipitate was filtered off on the sintered-glass plate and washed with three $2 \mathrm{ml}$. portions of water. The filtrate and washings were collected. The precipitate, after it had been dried to constant weight at $105^{\circ}$, weighed $0.03182 \mathrm{~g}$. It melted at $256-257^{\circ}$, and when it was mixed with phenolphthalein the melting point was unchanged. The sulphate present in the filtrate and washings yielded $0.04674 \mathrm{~g}$. $\mathrm{BaSO}_{4}$. Colorimetric analysis of the filtrate and washings obtained in a similar experiment showed that the phenolphthalein content was negligible $\left(<0.00005\right.$ g.). The phenolphthalein and sulphate (as $\left.\mathrm{SO}_{4}\right)$ liberated corresponded to 49.5 and $29.9 \%$, respectively, of the compound hydrolysed; potassium phenolphthalein disulphate dihydrate requires $49 \cdot 2 \%$ phenolpthalein and $29.7 \%$ sulphate.

Colorimetric determination of phenolphthalein liberated by hydrolysis of the compound. In all experiments other than that just described, a colorimetric method was used to determine phenolphthalein liberated by the acid or enzymic hydrolysis of potassium phenolphththalein disulphate. The procedure was as follows. To $5 \mathrm{ml}$. of the acid (or buffer) solution containing phenolphthalein, $\mathrm{NaOH}$ was added from a microburette until the solution was just pink (the concentration of the $\mathrm{NaOH}$ solution used was such that the volume required did not exceed $1 \mathrm{ml}$.). After water had been added to bring the volume of the solution to $6 \mathrm{ml}$., $4 \mathrm{ml}$. of buffer solution, $\mathrm{pH} \mathrm{10.4}$ (glycine- $\mathrm{NaOH}-\mathrm{NaCl}$, prepared as described by Talalay, Fishman \& Huggins (1946)) was added. The red colour of the solution (after dilution, if necessary) was then measured in a Spekker photoeletric absorptiometer (Adam Hilger Ltd.) using an Ilford no. 605 filter. The amount of phenolphthalein present was then calculated by reference to a standard curve obtained using known amounts of phenolphthalein. By this means it was possible to determine as little as $10 \mu \mathrm{g}$. of phenolphthalein in the original solution.

Experiments were carried out in which $1 \mathrm{ml}$. portions of a 0.01M-potassium phenolphthalein disulphate solution were heated in a boiling-water bath with $4 \mathrm{ml}$. portions of either $0.125 \mathrm{~N}-\mathrm{HCl}$ or $1.25 \mathrm{~N}-\mathrm{HCl}$. Under these conditions it was found that the compound was completely hydrolysed in $15 \mathrm{~min}$. in $0.1 \mathrm{~N}-\mathrm{HCl}$ and in $5 \mathrm{~min}$. in $\mathrm{N}-\mathrm{HCl}$.

Similar experiments were carried out at $37^{\circ}$, and under these conditions it was found that in $24 \mathrm{hr}$. $7 \cdot 8 \%$ of the phenolphthalein was liberated in $0.1 \mathrm{~N}-\mathrm{HCl}$ and $86.4 \%$ in N-HCl.

Enzymic hydrolysis of potassium phenolphthalein disulphate. Takadiastase, a commercial enzyme preparation from Aspergillus oryzae, shows arylsulphatase activity, and according to Huggins \& Smith (1947) the enzyme has an optimum $\mathrm{pH}$ of 6.12 at $37^{\circ}$ with a substrate of potassium 4-nitrophenylsulphate. In order to study the behaviour of potassium phenolphthalein disulphate on enzymic hydrolysis, experiments were carried out in which takadiastase was allowed to act on the compound at $37^{\circ}$. The enzyme solution was prepared by extracting $2.5 \mathrm{~g}$. of takadiastase diluted with talc (Parke Davis Co. Ltd.) with $50 \mathrm{ml}$. of water at room temperature. This gave a solution of takadiastase containing $0.37 \%$ solid matter, and $1 \mathrm{ml}$. portions of this were heated in a water bath at $37^{\circ}$ with $1 \mathrm{ml}$. of $0.01 \mathrm{~m}$ potassium phenolphthalein disulphate solution and $3 \mathrm{ml}$. of citrate-phosphate buffer, $\mathrm{pH}$ 6.2 (McIlvaine series; Britton, 1942). The amounts of phenolphthalein liberated were determined colorimetrically and the results obtained are shown in Table 1. No liberation of phenolphthalein took

\section{Table 1. Hydrolysis of potassium phenolphthalein disulphate by takadiastase}

(1 ml. 0.01 M substrate, $1 \mathrm{ml}$. $0.37 \%$ takadiastase, $3 \mathrm{ml}$. citrate-phosphate buffer, $\mathrm{pH} 6 \cdot 2$, at $37^{\circ}$.)

$\begin{array}{ccc}\text { Time } & \begin{array}{c}\text { Phenolphthalein } \\ \text { liberated } \\ (\mathrm{hr} .)\end{array} & \begin{array}{c}\text { Phenolphthalein } \\ \text { liberated } \\ (\mu \mathrm{g} .)\end{array} \\ 4 & 23 & 0 \cdot 73 \\ & 22 & 0 \cdot 69 \\ 8 & 52 & 1 \cdot 64 \\ & 51 & 1 \cdot 60 \\ 16 & 96 & 3 \cdot 02 \\ & 98 & 3 \cdot 08 \\ 24 & 143 & 4 \cdot 50 \\ & 140 & 4 \cdot 40\end{array}$

place in control experiments in which enzyme solution which had been heated in a boiling-water bath for $15 \mathrm{~min}$. was allowed to act on the substrate for $24 \mathrm{hr}$. under the conditions just described.

\section{Potassium 1-naphthylsulphate}

Synthesis of potassium 1-naphthylsulphate. This compound was synthesized by the method of Feigenbaum \& Neuberg (1941) using dimethylaniline as the organic base in the reaction. The potassium salt was purified by converting it to the $p$-toluidine salt by the procedure described by Barton \& Young (1943), recrystallizing this compound, and then converting it back to the potassium salt. The product gave negative tests for free naphthol (see below) and inorganic sulphate. It gave positive tests for naphthol and inorganic sulphate after it had been heated with $\mathrm{N}-\mathrm{HCl}$ in a boiling-water bath for 1 min. (Found: total sulphate $\mathrm{S}$, 12.4. Calc. for $\mathrm{C}_{10} \mathrm{H}_{7} \mathrm{O}_{4} \mathrm{SK}, 12 \cdot 2 \%$.)

Detection of 1-naphthol liberated by hydrolysis of potasssium 1-naphthylsulphate. 1-Naphthol was detected by the red colour it gives in alkaline solution with diazotized sulphanilic acid. The test was carried out by making the solution alkaline with $\mathrm{NaOH}$ solution and then adding freshly prepared diazo reagent (1 vol. of $0.8 \% \mathrm{NaNO}_{2}$ solution mixed with 9 vol. of a $0.25 \%$ solution of sulphanilic acid in $\mathrm{N}-\mathrm{HCl}$ ).

\section{Stability of the substrates under conditions used for bacteriological tests}

In the present investigation experiments were carried out in which bacteria were allowed to grow at $37^{\circ}$ for 7 days in media containing potassium 
phenolphthalein disulphate or potassium 1-naphthylsulphate. In the tests with Actinomyces the period of growth was 14 days. It was necessary, therefore, to determine whether any breakdown of the substrates took place under these conditions apart from that produced by the bacteria.

Into each of a series of glass-stoppered test tubes were placed $3 \mathrm{ml}$. citrate-phosphate buffer, $\mathrm{pH} 6 \cdot 0,7 \cdot 0$ or $8 \cdot 0$, $1 \mathrm{ml}$. of $0.01 \mathrm{~m}$-potassium phenolphthalein disulphate or $0.01 \mathrm{~m}$-potassium 1-naphthylsulphate, and $1 \mathrm{ml}$. of $0.1 \%$ 'Merthiolate' solution (Eli Lilly and Co. Ltd.) as a preservative. The tubes were placed in an incubator at $37^{\circ}$ and at intervals up to 28 days, tubes were removed and their contents tested for the presence of phenolphthalein or 1 . naphthol. No evidence of the breakdown of the substrates was obtained even after 28 days, i.e. after a period twice as long as the longest period used in the bacteriological tests.

As the media to which the substrates were added were sterilized by autoclaving at $15 \mathrm{lb}$./sq.in. pressure for $20 \mathrm{~min}$., it was also necessary to determine whether any liberation of phenolphthalein or 1-naphthol occurred during this process.

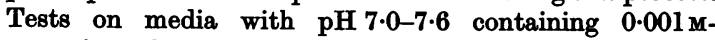
potassium phenolphthalein disulphate or 0.001 m-potassium 1-naphthylsulphate which had been sterilized in this way gave no evidence that hydrolysis of the substrates had taken place. Furthermore, there was no indication of hydrolysis after 2-3 months storage of the sterilized media at $4^{\circ}$. No detectable loss of the substrates occurred when their solutions were sterilized by Seitz filtration.

\section{THE DISTRIBUTION OF BACTERIAL ARYLSULPHATASE}

Apart from the investigations of Barber et al. (1951) on staphylococci, information appears to be lacking concerning the distribution of bacterial arylsulphatase. In the present work, various species of bacteria of medical interest have been examined for the occurrence of this enzyme. In order to test for the presence of the enzyme, the organisms were grown in a medium containing potassium phenolphthalein disulphate or potassium 1-naphthylsulphate, and the appearance of free phenolphthalein or 1-naphthol in the medium was taken as evidence of the production of arylsulphatase by the organism.

\section{Methods}

Preparation of media. An $0.01 \mathrm{~m}$ solution of the substrate (potassium phenolphthalein disulphate or potassium 1naphthylsulphate) in water was added to broth (pH 7·4-7.6) so as to produce a medium containing $1 \%$ meat extract (Lab Lemco, Oxo Ltd.), $1 \%$ peptone (Bacteriological Peptone, Evans Medical Supplies Ltd.), 0.5\% NaCl, and 0.001 $\mathrm{m}$ substrate. The medium was distributed in $4 \mathrm{ml}$. portions in $6 \times \frac{9}{16}$ in. tubes and autoclaved for $20 \mathrm{~min}$. at $15 \mathrm{lb} . / \mathrm{sq} . \mathrm{in}$. pressure.

For the cultivation of anaerobes, hot sterile vaseline was added to the tubes immediately after their removal from the autoclave. When cool, the medium was inoculated in the usual manner. The vaseline seal was first melted by gentle heat and, after the medium had been inoculated, the vaseline was allowed to re-seal the tube.
For certain species, where it was needed for growth, $0 \cdot 5 \mathrm{ml}$. sterile horse serum or blood was added to each tube after autoclaving, the tubes containing blood being brought to $100^{\circ}$ for 2-3 min. and well shaken. In some experiments the medium was enriched with $0.5 \%$ glucose.

Detection of arylsulphatase production by organisms grown in media containing phenolphthalein disulphate. The strain to be tested was inoculated into three tubes of broth containing $0.001 \mathrm{M}$-phenolphthalein disulphate, which were then incubated at $37^{\circ}$. One tube was tested for the presence of free phenolphthalein after 1 day, another after 3 days and the third after 7 days. Free phenolphthalein was detected by the addition of $\mathrm{N}-\mathrm{NaOH}$ until maximum development of colour had taken place. Decolorization of phenolphthalein takes place in strongly alkaline solutions, and the $\mathrm{NaOH}$ solution was therefore added carefully drop by drop with shaking of the contents of the tube. The depth of colour which developed was assessed visually and recorded according to the scale shown in Table 2.

Detection of arylsulphatase production by organisms grown in media containing potassium 1-naphthylsulphate. Each strain examined with this substrate was inoculated into three tubes of broth containing $0.001 \mathrm{~m}$-potassium 1 naphthylsulphate and also into three tubes of broth without substrate. Control experiments using broth without substrate were carried out because it was found that faintly positive diazo reactions were obtained after growth had occurred. After incubation at $37^{\circ}$ for 1 day a tube containing substrate and a control tube were removed and tested by means of the diazo reaction. The remaining tubes were tested after incubation for 3 and 7 days. The diazo test was carried out by adding to each tube $1 \mathrm{ml}$. of $2 \mathrm{~N}-\mathrm{NaOH}$ and $0.5 \mathrm{ml}$. of freshly prepared diazo reagent ( $1 \mathrm{ml} .0 .8 \%$ $\mathrm{NaNO}_{2}$ and $9 \mathrm{ml}$. $0.25 \%$ sulphanilic acid dissolved in $\mathrm{N}-\mathrm{HCl})$. The tubes were shaken and the difference in depth of colour between the tube containing naphthylsulphate and the control tube was assessed visually and recorded according to the scale shown in Table 2.

Sources of the strains studied. The strains examined were obtained from the following sources: the Stock Collection, Department of Bacteriology, St Thomas's Hospital Medical School; the Stock Collection and routine cultures, Louis Jenner Laboratory, St Thomas's Hospital; the Salmonella Reference Laboratory, Public Health Laboratory Service, Colindale; the National Collection of Type Cultures, Colindale. A collection of strains from cases of infantile gastro-enteritis was obtained from Dr G. S. Udall, St Thomas's Hospital Medical School.

The majority of the strains of salmonellae were inoculated directly from Dorset's egg medium. Strains of haemolytic streptococci, clostridia and corynebacteria were subcultured from Robertson's meat medium. The remainder were inoculated from nutrient or blood agar.

\section{Results}

Tests with potassium phenolphthalein disulphate as substrate. The number of strains tested with phenolphthalein disulphate as substrate was 212, and of these, fifty-four were found to show varying degrees of arylsulphatase activity. Among the organisms tested, the enzyme was found to be present in certain species of salmonellae and mycobacteria. For this reason the salmonellae and related bacteria 
were studied more extensively than the other groups. The examination of large numbers of mycobacteria, many of which require special methods for their cultivation, was considered to be outside the scope of the present work and it is being made part of a separate investigation (Whitehead, Wildy \& Engbaek, to be published).

Among seventy-nine strains of salmonellae, forty-seven strains belonging to fourteen species were found to give positive tests for the presence of arylsulphatase. No positive strains could be detected among nine strains of Salm. typhosa. Of the paratyphoid bacteria, all of the eleven strains of Salm. paratyphi tested, eight of twelve strains of Salm. schottmuelleri, and one of ten strains of Salm. hirschfeldii were found to give strongly positive tests. The strains of Salm. paratyphi showed somewhat weaker activity than the arylsulphatasepositive strains of the other paratyphoid bacteria. The four negative strains of Salm. schottmuelleri belonged to phage Types 1 and 2, and six of the positive strains to phage Types $3 a, 3 a \mathrm{I}$ and $3 b$. Unlike the paratyphoid organisms, the twentyseven positive strains found among thirty-seven strains of other species of salmonellae showed weak arylsulphatase activity. Among the related bacteria, no activity was detectable among twenty strains of Shigella, twenty-nine strains of Escherichia, Aerobacter and Klebsiella, and twenty-one strains of Proteus.

The ten strains of mycobacteria examined included four strains originally isolated from coldblooded animals. Of these four strains, two of Mycobact. piscium and one of Mycobact. ranae showed considerable activity, while a strain of Mycobact. chelonei was less active. Of the saprophytic acid-fast bacteria, two strains each of Mycobact. phlei, Mycobact. smegmatis and Mycobact. stercoris were tested. One strain of each species gave negative tests for arylsulphatase, and one strain of each species showed weak activity.

The following organisms, in addition to those already mentioned, gave no evidence of the production of arylsulphatase (where more than one strain was examined the number is shown in brackets): Actinomyces (anaerobic strain from human actinomycosis); Bacillus anthracis, B. subtilis (3), other Gram-positive sporing bacilli (5); Clostridium perfringens, Cl. septicum, Cl. sporogenes, Cl. tetani, Cl. tetanomorphum; Corynebacterium diphtheriae var. gravis, C. diphtheriae var. intermedius, C. diphtheriae var. mitis (3), C. pseudodiphtheriticum, $C$. xerose; Diplococcus pneumoniae; Gaffleya tetragena; Haemophilus influenzae, Haem. pertussis; Micrococcus lysodeikticus; Neisseria meningitidis (2); Pasteurella pestis; Pseudomonas aeruginosa (4); Sarcina; Serratia marcescens; Streptococcus faecalis (2), haemolytic streptococci (7), non-haemolytic streptococci (3), Strep. viridans (3); Vibrio comma (2).

Tests with potassium 1-naphthylsulphate as substrate. A number of tests for arylsulphatase were carried out using potassium 1-naphthylsulphate as substrate in order to find whether the results obtained would be similar to those from experiments in which phenolphthalein disulphate was used as substrate. Included in these tests were the majority of the salmonella strains which were negative or weakly positive, and a fow which were strongly positive when tested on a substrate of phenolphthalein disulphate. In all, fifty-seven strains of this group were tested with a substrate of potassium 1-naphththylsulphate. The results are included in Table 2, and they show that there is a broad measure of agreement in the results obtained with the two compounds, although in some instances hydrolysis of the substrate was detectable earlier when potassium 1-naphthylsulphate was used. In addition to the salmonella strains, the following sixteen strains from other genera were tested with potassium 1-naphthylsulphate as substrate and they yielded results in accordance with those obtained with phenolphthalein disulphate: Aerobacter aerogenes, B. anthracis, B. subtilis, Esch. coli (2), Klebsiella pneumoniae, Micrococcus epidermidis, M. pyogenes var. aureus, Mycobact. piscium, Past. pestis, Ps. aeruginosa, Proteus vulgaris (2), Shigella sonnei, Strep. pyogenes, V. comma.

During the examination of some strains in media containing potassium 1-naphthylsulphate it was observed that after incubation for $24 \mathrm{hr}$. or more there was a partial clearing of the turbidity of the cultures. It was noticed that this only occurred with strains which produced arylsulphatase and never with those which did not.

Experiments using a colourless medium. In an attempt to detect slight degrees of hydrolysis of phenolphthalein disulphate by bacteria, trials were made with this compound in a colourless medium consisting of $1 \%$ peptone (Bacteriological Peptone, Evans Medical Supplies Ltd.) and 0.5\% sodium chloride in water. The substrate concentration was $0.001 \mathrm{M}$. This medium was used for the examination of sixty-seven strains from various genera tested using the other medium. It was found that although slight hydrolysis of phenolphthalein disulphate could more easily be detected in the colourless medium, this advantage was outweighed by the poorer growth which occurred with many organisms. No additional arylsulphatase-producing strains were detected with the colourless medium.

Experiments with a medium containing $0.5 \%$ glucose. In order to determine whether the production of arylsulphatase is affected by the enhanced growth which many bacterial species show in media containing glucose, two strains known to 
produce the enzyme were grown in nutrient broth containing 0.001 M-phenolphthalein disulphate and, in addition, $0.5 \%$ glucose. No arylsulphatase activity could be detected after incubation for 7 days, although the organisms showed more vigorous growth than was observed in the absence of glucose. All the salmonellae which had been shown to produce the enzyme were therefore examined in broth containing $0.5 \%$ glucose and the substrate, and none showed any trace of arylsulphatase activity. Under the same conditions no activity could be detected in any of six strains of Mycobact. phlei, Mycobact. smegmatis and Mycobact. stercoris, whereas the four strains of Mycobact. piscium, Mycobact. ranae and Mycobact. chelonei showed no impairment of arylsulphatase activity when grown in broth containing $0.5 \%$ glucose. Twenty strains from various genera which were

Table 2. Results of testing seventy-nine strains of salmonellae for arylsulphatase activity using potassium phenolphthalein disulphate (I) and potassium 1-naphthylsulphate (II) as substrates.

(Substrate I. Colour on addition of alkali to the medium: \pm , faint tinge of pink; + , pale pink; ++ , pink; +++ , red; ++++ , deep red; - , no change in colour. Substrate II. Colour difference between control and medium containing substrate on addition of alkali and diazo reagent: \pm , just discernible; ++ , moderate; ++++ , marked; - , no difference. $\mathrm{NT}=$ strain not tested.)

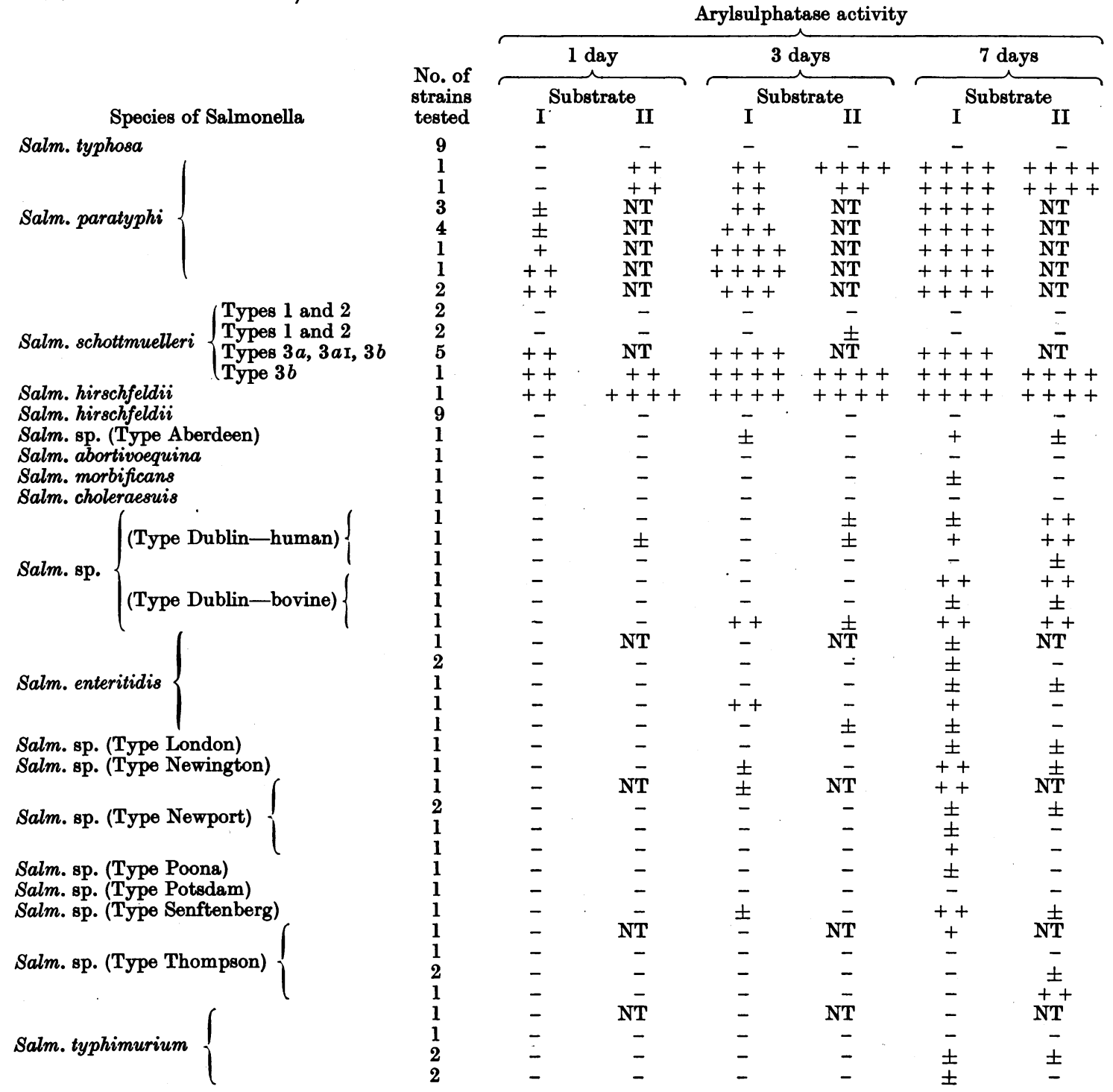


negative when tested in nutrient broth showed no arylsulphatase activity when grown in glucose broth.

Experiments under anaerobic conditions. Two strains of Salm. schottmuelleri and one of Salm. paratyphi which produced arylsulphatase when grown aerobically were cultured under anaerobic conditions by the methods described earlier. In each case visible growth was less than when these organisms were grown aerobically, but arylsulphatase production appeared to be only slightly diminished.

\section{SEPARATION AND PROPERTIES OF BACTERIAL ARYLSULPHATASE}

In order to study the properties of bacterial arylsulphatase, experiments designed to separate the enzyme from bacteria were undertaken. As a result of this work it was found possible to prepare cellfree aqueous solutions of arylsulphatase and these have been used for preliminary studies of the properties of the enzyme.

The organism from which arylsulphatase was separated was a subculture of Mycobact. piscium, N.C.T.C. No. 2291. This was obtained originally about 10 years ago from the National Collection of Type Cultures, and since then the strain has been maintained by monthly subculture on nutrient agar slopes. The original strain was isolated from the diseased roe of a halibut by Griffith (1930). This organism was selected for the present investigation because its arylsulphatase activity was high compared with that of other organisms which had been tested. Additional advantages attending its use were its lack of pathogenicity to man and the fact that its form of growth on a liquid medium is such that it can be harvested easily. At $37^{\circ}$ growth of the organism reaches a maximum after about 5-7 days and on liquid media it takes the form of a moderately tenacious yellowish grey pellicle with little subjacent turbidity or deposit, thus rendering harvesting by filtration a simple procedure.

Grouth and harvesting of the bacteria. The organism was grown in $4 \mathrm{oz}$. 'medical flat' bottles loosely plugged with cotton wool, each containing $30 \mathrm{ml}$. nutrient broth containing 0.001 M-potassium phenolphthalein disulphate. Inoculation was carried out by carefully floating on to the surface of the medium a portion of surface pellicle (approx. $1.5 \mathrm{~cm}$. in diameter) from a 3-5-day broth culture. The bottles were then incubated in a horizontal position so as to expose the greatest surface area of medium for growth of the organisms. The growth was harvested after 5-7 days incubation at $37^{\circ}$, by which time the surface of the medium was almost completely covered by the pellicle. The bacterial mass was separated by filtration on a Büchner funnel using a no. 1 Whatman paper and it was washed with about $100 \mathrm{ml}$. of distilled water for each bottle whose contents were filtered. Most of the excess moisture was removed by suction on the filter.
Extraction of the enzyme from the bacterial mass. Examination of the culture filtrate showed that its arylsulphatase activity was low. Attempts were made, therefore, to obtain active preparations of the enzyme by extracting the bacilli. No arylsulphatase activity was found in extracts obtained by handgrinding moist bacilli or acetone-dried bacilli in an agate mortar with saline-phosphate buffer at pH 7•0. In each case tests showed that the activity remained in the residue of the ground bacilli. Active preparations were obtained, however, when the technique of mechanical grinding of bacteria recommended by Dockstader \& Halvorson (1950) was employed. The procedure which was developed for the preparation of cell-free aqueous solutions of the enzyme was as follows.

The bacterial mass which had been separated by filtration on a Büchner filter and washed with distilled water was dried by repeated washing with acetone followed by suction. The dried material was scraped off the filter paper and weighed. It was then mixed with twice its weight of Hyflo Super-Cel (Johns-Manville Co. Ltd.) which had previously been washed three times with distilled water and dried. The mixture was placed in a homogenizer (Potter, 1945) and twice its volume of distilled water was added. The tube containing the mixture was immersed in an ice bath for $15 \mathrm{~min}$. while its contents were ground at about $1500 \mathrm{rev}$./ min. The viscid creamy material obtained by grinding was suspended in ice-cold distilled water $(1 \mathrm{ml} . / 5 \mathrm{mg}$. of acetonedried bacilli) and centrifuged at $1800 \mathrm{~g}$ for $30 \mathrm{~min}$. The opalescent supernatant liquid was decanted and filtered through a Gradocol collodion membrane (average pore diameter, $0.52 \mu$.) in an Elford ultrafilter to remove any remaining bacterial cells. The filtrate obtained was clear and showed only a very faint yellowish tinge. Dry weight determinations on two filtrates obtained in this way gave values of 1.42 and $1.57 \mathrm{mg} . / \mathrm{ml}$.

By means of the procedure just described it was possible to obtain cell-free solutions of arylsulphatase from bacilli grown in the presence of phenol. phthalein disulphate. Even when the procedure was modified by the omission of phenolphthalein disulphate from the medium the final solution obtained was found to contain the enzyme. Arylsulphatase was also separated from bacilli grown from an inoculum of organisms which had never been in contact with phenolphthalein disulphate.

Optimum pH of the enzyme. Experiments were conducted in which the enzyme was allowed to act on potassium phenolphthalein disulphate at various $\mathrm{pH}$ values ranging from $3 \cdot 0$ to $8 \cdot 0$. The experiments were carried out in glass-stoppered Pyrex test tubes into each of which was placed $3.0 \mathrm{ml}$. of citratephosphate buffer (McIlvaine series; Britton, 1942), $1.0 \mathrm{ml}$. of $0.01 \mathrm{M}$-potassium phenolphthalein disulphate and $1.0 \mathrm{ml}$. of unbuffered enzyme preparation. After $6 \mathrm{hr}$. in the water bath at $37^{\circ}$ the tubes were transferred to an ice bath and the free phenolphthalein was determined by the method 
described earlier in the present paper. The results obtained from duplicate experiments with each of two enzyme preparations are shown in Table 3. Experiments in which the $\mathrm{pH}$ values of the buffersubstrate-enzyme systems were determined electrometrically at the beginning and the end of the period of incubation revealed no significant change in pH. No detectable liberation of phenolphthalein occurred in $6 \mathrm{hr}$. at $37^{\circ}$ in control experiments in which water was used in place of enzyme solution at each $\mathrm{pH}$ value studied, or in which enzyme solution which had been heated in a boiling-water bath for $20 \mathrm{~min}$. was allowed to act on the substrate at pH 6.3.

Table 3. Optimum $\mathrm{pH}$ of arylsulphatase present in cell-free extracts of a strain of Mycobacterium piscium

(3.0 ml. citrate-phosphate buffer, $1.0 \mathrm{ml} .0 .01 \mathrm{M}$-potassium phenolphthalein disulphate, and $1.0 \mathrm{ml}$. enzyme solution at $37^{\circ}$ for $6 \mathrm{hr}$.)

\begin{tabular}{|c|c|c|}
\hline \multirow[b]{2}{*}{ pH } & \multicolumn{2}{|c|}{$\begin{array}{c}\text { Phenolphthalein liberated } \\
\left(\mu g_{.}\right)\end{array}$} \\
\hline & $\begin{array}{c}\text { Enzyme } \\
\text { preparation } A\end{array}$ & $\underset{\text { preparation } B}{\text { Enzyme }}$ \\
\hline $\begin{array}{l}3.0 \\
4 \cdot 0\end{array}$ & $\begin{array}{r}2 \\
12\end{array}$ & - \\
\hline $\begin{array}{l}\begin{array}{l}4.0 \\
5.0\end{array} \\
\text { a }\end{array}$ & 50 & - \\
\hline $5 \cdot 6$ & - & 21 \\
\hline 6.0 & 59 & 23 \\
\hline $6 \cdot 3$ & - & 24 \\
\hline 6.7 & - & 20 \\
\hline $7 \cdot 0$ & 47 & 16 \\
\hline $8 \cdot 0$ & 9 & - \\
\hline
\end{tabular}

Table 4. Optimum substrate concentration of arylsulphatase present in cell-free extracts of a strain of Mycobacterium piscium

(3.0 ml. citrate-phosphate buffer $\mathrm{pH} 6.3,1.0 \mathrm{ml}$. potassium phenolphthalein disulphate solution, and $1.0 \mathrm{ml}$. enzyme solution at $37^{\circ}$ for $6 \mathrm{hr}$.)

$\begin{array}{cc}\begin{array}{c}\text { Substrate concn. } \\ \text { in system } \\ (\mathbf{M})\end{array} & \begin{array}{c}\text { Phenolphthalein } \\ \text { liberated } \\ (\mu \mathrm{g} .)\end{array} \\ 0.0005 & 13 \\ 0 \cdot 0010 & 19 \\ 0.0020 & 21 \\ 0.0030 & 21 \\ 0.0040 & 20 \\ 0.0050 & 20\end{array}$

From the results given in Table 3 it appears that under the conditions employed the optimum $\mathrm{pH}$ of the arylsulphatase present in the extracts lay in the vicinity of $6 \cdot 3$.

Optimum substrate concentration. In order to determine the optimum substrate concentration a series of experiments was carried out in each of which $3.0 \mathrm{ml}$. of citrate-phosphate buffer $\mathrm{pH} 6.3$ and $1.0 \mathrm{ml}$. of enzyme solution were heated for $6 \mathrm{hr}$. at $37^{\circ}$ with $1.0 \mathrm{ml}$. of potassium phenolphthalein disulphate solution and the phenolphthalein liberated was determined colorimetrically by the method already described. The phenolphthalein disulphate solutions used were such that the concentrations of substrate in the system ranged from 0.0005 to $0.005 \mathrm{M}$ at the beginning of the experiment. The results obtained are shown in Table 4 from which it appears that the maximum velocity of arylsulphatase action occurred with a substrate concentration of $0.002-0.003 \mathrm{M}$.

\section{DISCUSSION}

As the present investigation involved the testing of many different bacteria for the presence of arylsulphatase, it was necessary first to devise a simple, sensitive test for the enzyme which could be applied in a medium suitable for the growth of a wide variety of organisms. Various substrates have been used for the qualitative and quantitative study of plant and animal arylsulphatase. These include potassium indoxyl sulphate (Derrien, 1911 ; Neuberg \& Wagner, 1925), potassium phenylsulphate (Neuberg \& Kurono, 1923; Abbott, 1947), and potassium 4-nitrophenylsulphate (Neuberg \& Wagner, 1925; Huggins \& Smith, 1947), and while the present work was in progress, Robinson, Smith \& Williams (1951) described the use of potassium 2-hydroxy-4-nitrophenylsulphate for the study of the enzyme. The use of these compounds has been based on the fact that on hydrolysis they yield phenolic products which can be detected or determined by their conversion to coloured compounds on treatment with suitable reagents. In applying this principle to the detection of bacterial arylsulphatase, consideration has to be given to the fact that culture media often have a yellow colour, and in consequence compounds which on hydrolysis yield phenols which are detected by their conversion to yellow products (e.g. potassium 4-nitrophenylsulphate) are unsatisfactory. In order to study bacterial phosphatase, Bray \& King (1942) used phthalein phosphates as substrates and later they made a study of the distribution of phosphatase in micro-organisms using phenolphthalein diphosphate as substrate (Bray \& King, 1943). Phenolphthalein offers a number of advantages as a chromogen, the chief of which are that the redcoloured form can be obtained merely by the addition of alkali, very small amounts of phenolphthalein are readily detected, and the colour reaction is not susceptible to interference by substances present in biological material. For these reasons phenolphthalein diphosphate has been used for work on phosphatases (Bray \& King, 1943; Huggins \& Talalay, 1945; Barber et al. 1951) and phenolphthalein glucuronide has been used for the 
study of $\beta$-glucuronidase in mammalian tissues (Talalay et al. 1946) and in micro-organisms (Barber et al. 1951). These various considerations led us to use phenolphthalein disulphate as an agent for testing for arylsulphatase. Some tests were also carried out with a monosulphate, potassium 1naphthylsulphate, as substrate, in order to determine whether the use of a different substrate would influence our conclusions concerning the distribution of arylsulphatase. The results obtained with this compound, however, were in general agreement with those obtained using phenolphthalein disulphate. As an agent for testing for arylsulphatase in bacteria, potassium 1-naphthylsulphate suffers from the disadvantage that it is necessary to run control experiments, for most organisms yield faintly positive diazo reactions after growth has occurred in the absence of the substrate.

The organisms tested for arylsulphatase activity in the present work did not include staphylococci or anaerobic cocci. The distribution of arylsulphatase among staphylococci has been investigated by Barber et al. (1951) and the distribution of the enzyme among anaerobic cocci has been studied in the course of an investigation by Prof. R. Hare \& Dr M. P. L. Wildy of the Bacteriology Department of this School (to be published). A wide variety of organisms was examined in the present work, and the results suggest that the possession of arylsulphatase in readily detectable amounts is not common among bacteria. Arylsulphatase activity was found in certain species of salmonella and mycobacteria, but with the methods used it could not be detected in any of the other species tested. The possibility should not be overlooked that the examination of larger numbers of strains of a particular species might reveal the occurrence of further arylsulphatase-producing organisms. It must also be recognized that, whereas a positive finding is significant in an investigation of this type, a negative finding does not necessarily exclude the possibility that the organism produces the enzyme. Variation of the cultural conditions or the use of a more sensitive method of testing might reveal the presence of the enzyme in an organism with weak arylsulphatase activity. In this connexion it should be noted that tests carried out on organisms of the Salmonella group with a monosulphate, potassium 1-naphthylsulphate, revealed the occurrence of weak arylsulphatase activity in a few strains earlier than when phenolphthalein disulphate was used as the substrate, although in most cases the two tests were in agreement. Another possibility which has to be considered is that the phenolic compound liberated from the substrate by the action of the enzyme might be metabolized by the organism and thus escape detection. This question is under investiga- tion by Whitehead, Wildy \& Engbaek (to be published) in their study of the arylsulphatase activity of mycobacteria using phenolphthalein disulphate as substrate, but no evidence has so far been obtained suggesting that utilization of phenolphthalein by these organisms (whether they produce arylsulphatase or not) occurs to an extent likely to affect the detection of the enzyme. Whether this is generally true of other bacterial species has not been established.

From a biochemical standpoint considerable interest attaches to the separation of the enzyme and the study of its properties. Among the various bacteria studied, one of the most active producers of arylsulphatase was a strain of Mycobact. piscium. Examination of the culture medium of this organism grown in the presence or the absence of phenolphthalein disulphate suggested that the medium contained little or no arylsulphatase. When the organism itself was separated and dried with acetone, it was found possible to prepare cell-free aqueous extracts which contained much of the arylsulphatase activity originally present in the dried organisms. These extracts were used for studies of the optimum $\mathrm{pH}$ and optimum substrate concentration of the enzyme. These preliminary experiments on the separation and properties of bacterial arylsulphatase have paved the way for more extensive biochemical studies of the enzyme.

\section{SUMMARY}

1. A description is given of the synthesis and properties of potassium phenolphthalein disulphate.

2. Potassium phenolphthalein disulphate has been used as a substrate for testing for the presence of arylsulphatase (phenolsulphatase) in 212 strains from a wide range of bacterial species, and seventythree of these strains have also been tested for the presence of this enzyme using potassium l-naphthylsulphate as substrate. The results obtained with the two substrates are in general agreement.

3. Under the test conditions, arylsulphatase has been detected only in certain strains of salmonellae and mycobacteria.

4. Cell-free aqueous extracts containing arylsulphatase have been prepared from $M$ ycobacterium piscium, N.C.T.C. 2291, and these have been used in a preliminary study of the properties of the enzyme.

The authors are indebted to Dr Joan Taylor, Salmonella Reference Laboratory, London, N.W. 9, the Curator, National Collection of Type Cultures, Dr G. S. Udall, and the Staff of the Louis Jenner Laboratory, St Thomas's Hospital, London, S.E. 1, for supplying them with various strains used in the investigation. 


\title{
REFERENCES
}

Abbott, L. D., jun. (1947). Fed. Proc. 6, 233.

Barber, M., Brooksbank, B. W. L. \& Kuper, S. W. A. (1951). J. Path. Bact. 68, 57.

Barton, A. D. \& Young, L. (1943). J. Amer. chem. Soc. 65, 294.

Bray, J. \& King, E. J. (1942). J. Path. Bact. 54, 287.

Bray, J. \& King, E. J. (1943). J. Path. Bact. 55, 315.

Britton, H. T. S. (1942). Hydrogen Ions, vol. I, 3rd ed. London: Chapman and Hall.

Burkhardt, G. N. \& Lapworth, A. (1926). J. chem. Soc. p. 684.

Czapek, E. (1914). Mh. Chem. 85, 635.

Derrien, M. (1911). Bull. Soc. chim. Fr. (4), 9, 110.

Dockstader, W. B. \& Halvorson, H. O. (1950). Science, 112 , 618.

Feigenbaum, J. A. \& Neuberg, C. (1941). J. Amer. chem. Soc. 63, 3529.

Fromageot, C. (1950). The Enzymes, ed. by Sumner, J. B. \& Myrbäck, K., vol. I, pt. 1, ch. 13. New York: Academic Press Inc.

Griffith, A. S. (1930). A System of Bacteriology, vol. v, ch. 5. London: H.M. Stationery Office.
Hommerberg, C. (1931). Hoppe-Seyl. Z. 200, 69.

Huggins, C. \& Smith, D. R. (1947). J. biol. Chem. 170, 391.

Huggins, C. \& Talalay, P. (1945). J. biol. Chem. 159, 399.

Neuberg, C. \& Kurono, K. (1923). Biochem. Z. 140, 295.

Neuberg, C. \& Simon, E. (1925). Biochem. Z. 156, 365.

Neuberg, C. \& Simon, E. (1932). Ergebn. Physiol. 34, 896.

Neuberg, C. \& Wagner, J. (1925). Biochem. Z. 161, 492.

Potter, V. R. (1945). Manometric Techniques and Related Methods for the Study of Tissue Metabolism, ed. by Umbreit, W. W., Burris, R. H. \& Stauffer, J. F., ch. 6. Minneapolis: Burgess.

Robinson, D., Smith, J. N. \& Williams, R. T. (1951). Biochem. J. 49, lxxiv.

Robinson, D., Spencer, B. \& Williams, R. T. (1951). Biochem. J. 48, xxviii.

Rosenfeld, L. (1925). Biochem. Z. 157, 434.

Talalay, P., Fishman, W. H. \& Huggins, C. (1946). J. biol. Chem. 166, 757.

Verley, A. (1901). Bull. Soc. chim. Fr. (3) 25, 46.

Young, L., Morrison, A. R. \& Whitehead, J. E. M. (1952). Nature, Lond., 169, 711.

\section{Microdetermination of Manganese in Biological Material by a Modified Catalytic Method}

\author{
By H. FORE AND R. A. MORTON \\ Biochemistry Department, University of Liverpool
}

(Received 3 November 1951)

In investigating the biochemical roles of manganese it is desirable to employ a very sensitive but reasonably accurate method of estimating the element. Methods based on the detection of manganese lines in emission spectra require the presence of about $50 \mu \mathrm{mg}$. of the element in a $10 \mathrm{mg}$. sample, and even when determinations are carried out in triplicate the accuracy obtainable is not great.

The periodate method, based on oxidation of the manganese to permanganate, which is determined by photoelectric colorimetry or spectrophotometry (Willard \& Greathouse, 1917; Richards, 1930; Strickland \& Spicer, 1949; Davidson \& Capen, 1929; Mehlig, 1939, 1941; Kirk, Rosenfels \& Hanahan, 1947 ; Rowland, 1939) is generally satisfactory. The main disadvantage of the periodate method is that the amount of tissue needed to provide the necessary minimum of manganese is quite often larger than that available. The colorimetric estimation of manganese by means of the Folin-Ciocalteu reagent (Abul-Fadl, 1948) requires at least $12 \mu \mathrm{g}$. manganese.
Szebelledy \& Bartfai (1936) described a catalytic method for the detection of manganese in amounts less than $1 \mu \mathrm{mg}$., and Kun (1947) worked out a quantitative procedure, using photoelectric spectrophotometry. Manganous ions catalyse the oxidation of $N N$-diethylaniline by potassium metaperiodate $\left(\mathrm{KIO}_{4}\right)$ in aqueous solution, and the progress of the oxidation can be followed by measuring the increasing absorption of light at $470 \mathrm{~m} \mu$. Kun used a medium buffered at pH 7.0 and measured the extinction exactly 200 sec. after mixing the reagents. He found no interference by ions of other metals. Each test required at least $4 \mu \mathrm{mg}$. of manganese, but Kun found it necessary to make many readings so as to eliminate the effect of what appeared to be random variations.

The catalytic method appeared to be very promising, but a considerable study of all the variables was necessary before it could be applied with confidence to the problems of determining manganese in very small amounts of tissues. The final procedure adopted will first be described and then discussed. 